\title{
ON THE ECONOMICS OF BOTTLE DEPOSITS
}

\author{
WOLFGANG EGGERT \\ ALFONS J. WEICHENRIEDER
}

CESIFO WORKING PAPER No. 1243

CATEGORY 1: PUBLIC FINANCE

JULY 2004

An electronic version of the paper may be downloaded

- from the SSRN website:

www.SSRN.com

- from the CESifo website:

www.CESifo.de 


\title{
ON THE ECONOMICS OF BOTTLE DEPOSITS
}

\begin{abstract}
Deposit systems for one-way beverage containers are widely supported by green activists and have been implemented in several countries. This paper analyzes whether such deposit systems can optimally internalize the externalities that result when consumers dump these containers. It is shown that two major problems arise in a competitive market. First, the proceeds from bottle deposits tend to reduce the price of beverages in a competitive environment and therefore lead to a departure from a first best allocation. Second, the system usually requires producers and vendors to run a system for taking back and recycling used containers, whose cost vendors can only partly shift to consumers who return their bottles. While a deposit system alone is never optimal, the paper proposes tax-deposit systems that can implement a first-best allocation.
\end{abstract}

JEL Code: H23, Q20, H21.

Wolfgang Eggert

Ifo Institute for Economic Research at the University of Munich

Poschingerstr. 5

81679 Munich

Germany

eggert@ifo.de
Alfons J. Weichenrieder

Goethe-University Frankfurt

Faculty of Economics and Business

Administration

60054 Frankfurt (Main)

Germany

a.weichenrieder@em.uni-frankfurt.de 


\section{Introduction}

Many politicians and green activists fear that one-way containers for soft drinks will lead to costs that are not fully taken into account in the decisions of consumers and producers. A first type of externality may occur even when one-way containers are returned by consumers for recycling. It may result if market prices of the resources employed in the production of one-way containers do not reflect the external effects of factor utilization. For example, container producers may overuse energy and raw materials if the market prices of the inputs employed in the production process do not reflect the costs of global warming or, more generally, pollution. Second, the use of one-way containers may produce additional externalities if those containers are not returned. For example, consumers may not have the correct incentives to save on refuse by returning the one-way containers or may even litter the environment unless there is government intervention. ${ }^{1}$ And distorted raw materials prices, the public good characteristic of an unlittered environment and the cost of recycling may also limit the incentives producers have to induce consumers to return bottles for further use. ${ }^{2}$

For economists, the standard approach to tackling externalities is to levy a Pigouvian tax targeted on internalizing the external effects, and green taxes have indeed been introduced widely in Europe. ${ }^{3}$ In the case of one-way containers for beverages, however, a recent policy reform in Germany introduced a system of government enforced deposit charges for one-way containers, even though a tax had been discussed as a possible alternative solution. ${ }^{4}$ Obligatory deposits on one-way containers are also to be found in some ten U.S. States, in the Canadian provinces British Columbia and Alberta, and in Sweden.

\footnotetext{
${ }^{1}$ Bohm (1981, 103-115) gives an excellent overview of various government objectives that may motivate mandatory deposits and surveys the social cost that results from one-way containers.

${ }^{2}$ Throughout the paper we will use the terms "one-way containers" and "bottles" as synonyms.

${ }^{3}$ For a survey, see OECD (2001).

${ }^{4}$ In the German discussion that preceded the introduction of the bottle deposit, the Retailers Association had preferred a tax on tins instead of the deposit (see Vorholz 2002).
} 
One possible advantage of a deposit system is that it discriminates between containers that are returned for recycling and those containers that are simply dumped by consumers. While consumers who do not return the containers have to pay the deposit, consumers who do return them get back their deposit. This feature may make a deposit a suitable instrument for tackling the second type of externalities mentioned above - those externalities that could be eliminated by returning the one-way containers. The optimal reaction to this type of externality is at the heart of the present paper and here we explore the question of whether, in such a setting, a deposit is an optimal policy instrument

One important difference between a deposit and a tax is that, while the latter accrues to the government, the former is collected by the producers or vendors and they may receive a net revenue from the deposit if not all containers are returned by consumers. In a competitive equilibrium, this additional revenue will have feedback effects on the price of beverages and will distort the prices between drinks sold in in-way containers and other goods. The paper shows that, because of this price distorting effect, a deposit system is normally not an optimal instrument for correcting the externalities that result from dumping one-way containers. While a deposit system alone is never optimal, the paper suggests some tax-deposit systems that can implement a first-best allocation.

\section{A Simple Model of Enforced Bottle Deposits}

\subsection{The Central Planner Problem}

For consumers, there are two methods for consuming a beverage provided in one-way containers. Method A is to drink the beverage and dump the container. Method B is to drink the beverage and incur the cost of returning the beverage to the vendor or a system financed by the vendor for recycling. In most instances, though not necessarily in all, consumers find it more convenient to dump the container rather than return it. The amount of beverages 
consumed using method $\mathrm{A}$ is denoted by $X$, the number of beverages consumed using method B is denoted by $Y$.

The external environmental cost that occurs when method $\mathrm{A}$ is used instead of method $\mathrm{B}$ is denoted by $\theta(X)$, with $\theta^{\prime}, \theta^{\prime \prime}>0$. This cost may include the disadvantage of littering or the external costs of resource use that could be saved by recycling. If a deposit system is in place, the government is assumed to enforce recycling and vendors of the beverages incur recycling costs $R(Y)$. The costs of recycling must be interpreted in a broad sense. They include all costs of running the system to collect, process, and dispose of used containers according to government regulation minus revenues from selling the processed containers for further use.

Consumers find it more convenient not to return at least some of the used containers and total consumer surplus from consuming beverages in one-way containers can be expressed by the function

$$
Q=Q(X+Y, S(Y))
$$

where $\partial Q / \partial(X+Y)>0, \partial Q / \partial S<0, \partial^{2} Q / \partial S^{2}<0, \partial S / \partial Y \geq 0, \partial^{2} S / \partial Y^{2}>0$. The first argument of $Q$ represents the positive utility from consumed beverages, while the second argument captures the inconvenience of returning bottles, a cost to the representative consumer that is assumed to be convex in $Y$. In cases where the beverage is consumed immediately at the shop this inconvenience cost of returning may be low, in others where, for example, bottles have been bought for consumption on a cheap airline flight, this cost may be almost prohibitive.

A welfare maximizing social planner who wants to maximize consumer surplus minus production cost, external cost $\theta$ and recycling cost $\mathrm{R}$ solves the following problem:

$$
\max _{X, Y} Q(\overbrace{X+Y}^{(+)}, \overbrace{S(Y)}^{(-)})-\theta(X)-c(X+Y)-R(Y),
$$


where $c(X+Y)$ denotes the production cost of the beverages sold in one-way containers (excluding the external cost of dumped containers). Assuming an interior solution $(X, Y>0)$, the two first order conditions for an optimal solution read:

$$
\partial Q / \partial Y+(\partial Q / \partial S) \cdot(\partial S / \partial Y)=\partial c / \partial Y+\partial R / \partial Y
$$

Since by construction, $\partial Q / \partial X=\partial Q / \partial Y$ and $\partial c / \partial X=\partial c / \partial Y$, this implies that

$$
\partial \theta / \partial X=\partial R / \partial Y-(\partial Q / \partial S) \cdot(\partial S / \partial Y)
$$

In an interior optimum, according to equation (3), the marginal externality of dumping the bottles equals the marginal cost of recycling minus the marginal inconvenience cost of returning the bottles. Equations (1) and (2) characterize the socially optimal solution, and we discuss the market outcome in alternative scenarios against this benchmark in the following.

\subsection{Market Outcome with a Bottle Deposit}

In the next step we want to inquire whether a bottle deposit on one-way containers is able to implement the optimal solution. First we need to model the producer side. We condense the distribution chain into a single production and distribution process. That is, a representative price taking firm faces costs $c$ depending on the total units of beverages $Z$ produced and sold. Marginal costs are non-decreasing in $Z$. The representative consumer buys these beverages and decides what part $X$ to consume according to method A (drink and dump) and what part to consume according to method B (drink and return to the vendor). That is $X+Y=Z$.

As in the central planner problem, recycling costs are given by $R(Y)$ and depend on the number of returned bottles only. If a bottle deposit $D$ is enforced by the government, this deposit must be charged by the representative firm for all units sold, leading to total deposits 
of $Z \cdot D$. However, a refund of $Y \cdot D$ has to be given for returned bottles leaving the representative firm with a net revenue of $X \cdot D$. Allowing a tax at the rate $t(0 \leq t \leq 1)$ on this revenue earns the firm a net of tax deposit income of $X \cdot D(1-t) .^{5}$

The price taking firm is observing the market price $P$ for beverages sold in one-way containers. It also observes that at the given price and deposit the fraction $\gamma$ of all containers is returned by consumers. ${ }^{6}$ Hence, it will solve the problem

$$
\max _{Z} P \cdot Z+Z \cdot D(1-t)(1-\gamma)-c(Z)-R(\gamma \cdot Z) .
$$

The first order condition is given by

$$
P=\partial c / \partial Z+\gamma \cdot \partial R / \partial Y-D(1-t)(1-\gamma)
$$

The interpretation of (4) is straightforward. The profit-maximizing firm chooses a level of production $Z$ such that the price plus the average retained deposits per unit sold are equal to the marginal cost of production and the expected marginal cost of recycling.

The representative consumer is assumed to have an exogenous income and will try to maximize her net consumer surplus of

$$
V=Q(X+Y, S(Y))-D \cdot X-P \cdot(X+Y) \text {. }
$$

The necessary conditions for an interior household optimum then are

$$
\partial Q / \partial Y+(\partial Q / \partial S) \cdot(\partial S / \partial Y)=P
$$

which together imply:

$$
-(\partial Q / \partial S) \cdot(\partial S / \partial Y)=D
$$

\footnotetext{
${ }^{5}$ Note that in Germany, for example, the income from non-redeemed deposits is subject to the value added tax (VAT).

${ }^{6}$ In the U.S. the recovery rate of beverage containers in states that have introduced a deposit between $2 \frac{1}{2}$ and 10 U.S. cent seems to range between 73 percent and 95 percent (see GRRN 2003).
} 
The representative consumer will return all bottles for which the inconvenience costs of returning fall short of the lost deposit in the case of dumping and she will dump all bottles for which the inconvenience of returning exceeds the deposit. Therefore, in line with equation (7), the marginal inconvenience cost of returning bottles will equal the deposit.

From (4), (5), and (6) we have that in a market equilibrium the following conditions must hold:

$$
\begin{gathered}
\partial Q / \partial X=\partial c / \partial X+\gamma \cdot \partial R / \partial Y-D(1-t)(1-\gamma)+D \\
\partial Q / \partial Y+(\partial Q / \partial S) \cdot(\partial S / \partial Y)=\partial c / \partial Y+\gamma \cdot \partial R / \partial Y-D(1-t)(1-\gamma)
\end{gathered}
$$

A first-best allocation requires a policy $(D, t)$, so that equation (8) reproduces the optimality condition (1), and equation (9) reproduces the optimality condition (2). Equality of (8) and (1) requires

$$
D=\frac{\partial \theta / \partial X-\gamma \partial R / \partial Y}{(1-t)(1-\gamma)+1}
$$

while equality of (9) and (2) requires

$$
(1-t) D=-\partial R / \partial Y
$$

Since marginal recycling costs are positive and $0 \leq t \leq 1$, optimality in an interior solution $(\gamma<1)$, on the one hand, requires a negative deposit according to equation (11), while, on the other hand, equation (10) requires a positive deposit as long as the marginal externality from dumping a bottle exceeds marginal recycling costs times the fraction of bottles returned. ${ }^{7}$ Note that this relationship must be fulfilled if recycling is to be economically worthwhile. From this we have proven

PROPOSITION 1: If the socially optimal recycling rate is less than unity $(\gamma<1)$ and the marginal recycling cost is positive, then a deposit cannot implement a first-best allocation.

\footnotetext{
${ }^{7}$ A negative deposit cannot, of course, be implemented if returning the bottles is voluntary for consumers.
} 
Inspection of equations (10) and (11) also shows that the optimal solution could be implemented if the marginal recycling cost was zero $(\partial R / \partial Y=0)$. This would then require choosing a simple Pigouvian tax. The government has to set $D$ according to equation (10), implying that all the revenues of the deposit system are taxed at 100 percent $(t=1)$. Essentially, this system would raise a tax on all one-way containers sold but not taken back by the vendors. The tax rate would internalize the externality of dumping the bottles. A simple deposit system that leaves deposit revenue to vendors would not do an optimal job. We summarize this result in

PROPOSITION 2: If the optimal recycling rate is less than unity and the marginal recycling cost is zero, then a deposit alone cannot implement a first-best allocation but a Pigouvian tax on one-way containers sold but not taken back by the vendors can be used as an optimal policy instrument.

\subsection{Subsidizing or Taxing Recycling}

If recycling creates costs for firms, the problem with the Pigouvian solution is that the government shifts some of the costs of reducing the externality to firms without giving them adequate compensation. Therefore one could be induced to think that a remedy would be to give the government an additional policy instrument for taking over the marginal cost of recycling from firms (or alternatively make recycling more expensive). To examine this possibility, assume that the government pays a (possibly negative) subsidy of $\tau$ per bottle returned. In this case the objective of the representative firm changes to

$$
\max _{Z} P \cdot Z+Z \cdot D(1-t)(1-\gamma)-c(Z)-R(\gamma \cdot Z)+\tau \cdot \gamma \cdot Z
$$

with the first order condition 


$$
P=\partial c / \partial Z+\gamma \cdot \partial R / \partial Y-\tau \cdot \gamma-D(1-t)(1-\gamma)
$$

Hence, equations (8) and (9), which characterize the market solution, read

$$
\begin{gathered}
\partial Q / \partial X=\partial c / \partial X+\gamma \cdot \partial R / \partial Y-\tau \cdot \gamma-D(1-t)(1-\gamma)+D \\
\partial Q / \partial Y+(\partial Q / \partial S) \cdot(\partial S / \partial Y)=\partial c / \partial X+\gamma \cdot \partial R / \partial Y-\tau \cdot \gamma-D(1-t)(1-\gamma)
\end{gathered}
$$

Comparing these expressions with the optimality conditions (1) and (2), we have that an optimal policy $(D, t, \tau)$ must simultaneously comply with

$$
\gamma \cdot \partial R / \partial Y-\tau \cdot \gamma-D(1-t)(1-\gamma)+D=\partial \theta / \partial X
$$

and

$$
\gamma \cdot \partial R / \partial Y-\tau \cdot \gamma-D(1-t)(1-\gamma)=\partial R / \partial Y
$$

From (15) and (16) we immediately see that a Pigouvian tax on non-returned bottles plus a subsidy to producers to cover marginal recycling costs $\left(t=1, D=\theta^{\prime}, \tau=R^{\prime}\right)$ is not optimal. The problem of such a system would be that a consumer who returns her bottles does not incur the costs of recycling and therefore faces too low a price. Nevertheless, the introduction of the new instrument allows policy combinations that replicate the first-best allocation. Assume the government $\operatorname{sets} D=\partial \theta / \partial X-\partial R / \partial Y, t=1$. Then choosing a negative subsidy on recycled bottles $\tau=-(\partial R / \partial Y) \cdot(1-\gamma) / \gamma$ fulfils both of the above conditions and is available to implement the optimal solution.

At face value, the result that a tax on recycling is part of an optimal solution seems surprising. After all, too few bottles are recycled in the laissez-faire equilibrium. But the problem of the vendor is that, when a customer buys beverages, the vendor cannot predict whether the customer will come back and so force the vendor to incur the recycling cost. Hence, in a competitive setting, the vendor will only charge the expected recycling cost and the customer who actually brings back her bottles gets away with a price that is too low to 
cover the full marginal costs of recycling. The tax, coupled with a deposit that falls short of the marginal externality $\theta^{\prime}$, however, does the job.

PROPOSITION 3: If the optimal recycling rate is less than unity and the marginal recycling cost is positive, then a possible optimal solution consists of a tax on recycled bottles, plus a deposit system whose net revenues are taxed away by the government.

Essentially, this system mimics a set of two Pigouvian taxes. One applies to bottles that are returned for recycling. The other one applies to bottles dumped by consumers.

Clearly, with three instruments and only two restrictions, the government has an infinite number of optimal policies. An alternative scenario to the one described in Proposition 3 is one where the government sets $\mathrm{t}=0$. In this case, the solution to the equation system (15) and (16) is given by $D=\theta^{\prime}-R^{\prime} ; \tau=\theta^{\prime}(\gamma-1) / \gamma$. Again, recycled bottles are taxed rather than subsidized, leading us to formulate:

PROPOSITION 4: If the government wants to implement an optimal solution with a nontaxable deposit, then the deposit should cover the difference between the marginal externality of dumping containers and recycling containers. This deposit has to be combined with a tax on recycled containers that equals the product of the marginal externality of dumping and the optimal ratio of non-returned and returned containers.

\section{Conclusion}

As far as we know, this paper is the first to formally analyze whether a bottle deposit is an appropriate measure for internalising the possible external effects of using one-way beverage containers. We have shown that setting the deposit equal to the marginal externality that results from dumped containers is not compatible with an interior optimum in which some containers are not returned. Such a scenario covers the realistic case where 
cost of returning the container may be prohibitive, at least for some beverages. The present paper has shown that, in this plausible case, an efficient optimum cannot be reached with a deposit alone. An important reason is that the revenues go to the vendor and distort the prices of beverages (sold in one-way containers) and other goods. If recycling is costly to firms, then even a Pigouvian tax on non-returned one-way containers is suboptimal. The reason is that, in this case, consumers would not internalize the full marginal recycling cost and at least two policy instruments are needed.

While we think that we have highlighted aspects that are at the green heart of the idea behind bottle deposits, we should note that the present paper has left out some other important aspects of bottle deposits. One group of proponents of bottle deposits are small local producers of beverages who hope to gain an advantage over large competitors who may find it more difficult to take back containers. In a similar vein, the EU has recently expressed great concern about the trade restriction that may accompany certain deposit systems. We plan to address those special aspects of bottle deposits in future work. 
Bibliography

Bohm, P. (1981), Deposit-refund systems. Theory and applications to environmental, conservation, and consumer policy. Baltimore and London: Johns Hopkins Press.

GRRN (2003), "Beverage container producer responsibility campaign: Essential elements of a beverage container recovery system", www.grrn.org/beverage/deposits/ essential_elements.html, November 2003.

OECD (2001), Environmentally Related Taxes in OECD Countries: Issues and Strategies, Paris: OECD.

Vorholz, F. (2002), "Tanz um die Dose", Die Zeit, 52/2002. 


\section{CESifo Working Paper Series}

(for full list see www.cesifo.de)

1178 Stefan Lachenmaier and Ludger Woessmann, Does Innovation Cause Exports? Evidence from Exogenous Innovation Impulses and Obstacles, April 2004

1179 Thiess Buettner and Johannes Rincke, Labor Market Effects of Economic Integration The Impact of Re-Unification in German Border Regions, April 2004

1180 Marko Koethenbuerger, Leviathans, Federal Transfers, and the Cartelization Hypothesis, April 2004

1181 Michael Hoel, Tor Iversen, Tore Nilssen, and Jon Vislie, Genetic Testing and Repulsion from Chance, April 2004

1182 Paul De Grauwe and Gunther Schnabl, Exchange Rate Regimes and Macroeconomic Stability in Central and Eastern Europe, April 2004

1183 Arjan M. Lejour and Ruud A. de Mooij, Turkish Delight - Does Turkey's accession to the EU bring economic benefits?, May 2004

1184 Anzelika Zaiceva, Implications of EU Accession for International Migration: An Assessment of Potential Migration Pressure, May 2004

1185 Udo Kreickemeier, Fair Wages and Human Capital Accumulation in a Global Economy, May 2004

1186 Jean-Pierre Ponssard, Rent Dissipation in Repeated Entry Games: Some New Results, May 2004

1187 Pablo Arocena, Privatisation Policy in Spain: Stuck Between Liberalisation and the Protection of Nationals' Interests, May 2004

1188 Günter Knieps, Privatisation of Network Industries in Germany: A Disaggregated Approach, May 2004

1189 Robert J. Gary-Bobo and Alain Trannoy, Efficient Tuition Fees, Examinations, and Subsidies, May 2004

1190 Saku Aura and Gregory D. Hess, What's in a Name?, May 2004

1191 Sjur Didrik Flåm and Yuri Ermoliev, Investment Uncertainty, and Production Games, May 2004

1192 Yin-Wong Cheung and Jude Yuen, The Suitability of a Greater China Currency Union, May 2004 
1193 Inés Macho-Stadler and David Pérez-Castrillo, Optimal Enforcement Policy and Firms' Emissions and Compliance with Environmental Taxes, May 2004

1194 Paul De Grauwe and Marianna Grimaldi, Bubbles and Crashes in a Behavioural Finance Model, May 2004

1195 Michel Berne and Gérard Pogorel, Privatization Experiences in France, May 2004

1196 Andrea Galeotti and José Luis Moraga-González, A Model of Strategic Targeted Advertising, May 2004

1197 Hans Gersbach and Hans Haller, When Inefficiency Begets Efficiency, May 2004

1198 Saku Aura, Estate and Capital Gains Taxation: Efficiency and Political Economy Consideration, May 2004

1199 Sandra Waller and Jakob de Haan, Credibility and Transparency of Central Banks: New Results Based on Ifo's World Economicy Survey, May 2004

1200 Henk C. Kranendonk, Jan Bonenkamp, and Johan P. Verbruggen, A Leading Indicator for the Dutch Economy - Methodological and Empirical Revision of the CPB System, May 2004

1201 Michael Ehrmann, Firm Size and Monetary Policy Transmission - Evidence from German Business Survey Data, May 2004

1202 Thomas A. Knetsch, Evaluating the German Inventory Cycle - Using Data from the Ifo Business Survey, May 2004

1203 Stefan Mittnik and Peter Zadrozny, Forecasting Quarterly German GDP at Monthly Intervals Using Monthly IFO Business Conditions Data, May 2004

1204 Elmer Sterken, The Role of the IFO Business Climate Indicator and Asset Prices in German Monetary Policy, May 2004

1205 Jan Jacobs and Jan-Egbert Sturm, Do Ifo Indicators Help Explain Revisions in German Industrial Production?, May 2004

1206 Ulrich Woitek, Real Wages and Business Cycle Asymmetries, May 2004

1207 Burkhard Heer and Alfred Maußner, Computation of Business Cycle Models: A Comparison of Numerical Methods, June 2004

1208 Costas Hadjiyiannis, Panos Hatzipanayotou, and Michael S. Michael, Pollution and Capital Tax Competition within a Regional Block, June 2004

1209 Stephan Klasen and Thorsten Nestmann, Population, Population Density, and Technological Change, June 2004

1210 Wolfgang Ochel, Welfare Time Limits in the United States - Experiences with a New Welfare-to-Work Approach, June 2004 
1211 Luis H. R. Alvarez and Erkki Koskela, Taxation and Rotation Age under Stochastic Forest Stand Value, June 2004

1212 Bernard M. S. van Praag, The Connexion Between Old and New Approaches to Financial Satisfaction, June 2004

1213 Hendrik Hakenes and Martin Peitz, Selling Reputation When Going out of Business, June 2004

1214 Heikki Oksanen, Public Pensions in the National Accounts and Public Finance Targets, June 2004

1215 Ernst Fehr, Alexander Klein, and Klaus M. Schmidt, Contracts, Fairness, and Incentives, June 2004

1216 Amihai Glazer, Vesa Kanniainen, and Panu Poutvaara, Initial Luck, Status-Seeking and Snowballs Lead to Corporate Success and Failure, June 2004

1217 Bum J. Kim and Harris Schlesinger, Adverse Selection in an Insurance Market with Government-Guaranteed Subsistence Levels, June 2004

1218 Armin Falk, Charitable Giving as a Gift Exchange - Evidence from a Field Experiment, June 2004

1219 Rainer Niemann, Asymmetric Taxation and Cross-Border Investment Decisions, June 2004

1220 Christian Holzner, Volker Meier, and Martin Werding, Time Limits on Welfare Use under Involuntary Unemployment, June 2004

1221 Michiel Evers, Ruud A. de Mooij, and Herman R. J. Vollebergh, Tax Competition under Minimum Rates: The Case of European Diesel Excises, June 2004

1222 S. Brock Blomberg and Gregory D. Hess, How Much Does Violence Tax Trade?, June 2004

1223 Josse Delfgaauw and Robert Dur, Incentives and Workers' Motivation in the Public Sector, June 2004

1224 Paul De Grauwe and Cláudia Costa Storti, The Effects of Monetary Policy: A MetaAnalysis, June 2004

1225 Volker Grossmann, How to Promote R\&D-based Growth? Public Education Expenditure on Scientists and Engineers versus R\&D Subsidies, June 2004

1226 Bart Cockx and Jean Ries, The Exhaustion of Unemployment Benefits in Belgium. Does it Enhance the Probability of Employment?, June 2004

1227 Bertil Holmlund, Sickness Absence and Search Unemployment, June 2004 
1228 Klaas J. Beniers and Robert Dur, Politicians' Motivation, Political Culture, and Electoral Competition, June 2004

1229 M. Hashem Pesaran, General Diagnostic Tests for Cross Section Dependence in Panels, July 2004

1230 Wladimir Raymond, Pierre Mohnen, Franz Palm, and Sybrand Schim van der Loeff, An Empirically-Based Taxonomy of Dutch Manufacturing: Innovation Policy Implications, July 2004

1231 Stefan Homburg, A New Approach to Optimal Commodity Taxation, July 2004

1232 Lorenzo Cappellari and Stephen P. Jenkins, Modelling Low Pay Transition Probabilities, Accounting for Panel Attrition, Non-Response, and Initial Conditions, July 2004

1233 Cheng Hsiao and M. Hashem Pesaran, Random Coefficient Panel Data Models, July 2004

1234 Frederick van der Ploeg, The Welfare State, Redistribution and the Economy, Reciprocal Altruism, Consumer Rivalry and Second Best, July 2004

1235 Thomas Fuchs and Ludger Woessmann, What Accounts for International Differences in Student Performance? A Re-Examination Using PISA Data, July 2004

1236 Pascalis Raimondos-Møller and Alan D. Woodland, Measuring Tax Efficiency: A Tax Optimality Index, July 2004

1237 M. Hashem Pesaran, Davide Pettenuzzo, and Allan Timmermann, Forecasting Time Series Subject to Multiple Structural Breaks, July 2004

1238 Panu Poutvaara and Andreas Wagener, The Invisible Hand Plays Dice: Eventualities in Religious Markets, July 2004

1239 Eckhard Janeba, Moral Federalism, July 2004

1240 Robert S. Chirinko, Steven M. Fazzari, and Andrew P. Meyer, That Elusive Elasticity: A Long-Panel Approach to Estimating the Capital-Labor Substitution Elasticity, July 2004

1241 Hans Jarle Kind, Karen Helene Midelfart, Guttorm Schjelderup, Corporate Tax Systems, Multinational Enterprises, and Economic Integration, July 2004

1242 Vankatesh Bala and Ngo Van Long, International Trade and Cultural Diversity: A Model of Preference Selection, July 2004

1243 Wolfgang Eggert and Alfons J. Weichenrieder, On the Economics of Bottle Deposits, July 2004 